\title{
STRATEGIC IMPLEMENTATION OF CORPORATE IDENTITY IN A DESIGN COMPANY
}

\author{
Yunida Sofiana \\ Department of Interior Design, School of Design, BINUS University \\ Jln. K. H. Syahdan No. 9, Palmerah, Jakarta Barat 11480 \\ ysofiana@binus.edu
}

\begin{abstract}
Implementation of Corporate Identity has been increase enormously over the past 20 years and predicting will be increase higher in the future. Design Company will be the one who will get the big impact from these changes. Business world believes that corporate identity as important aspect to consider if they want to succeed and competed in their business. An important part of this article is to learn about corporate identity from the literatures and then apply that knowledge and the experiences gained to discuss the strategic implementation of a corporate identity within Design Company. Many companies especially design companies try very hard and seriously to develop a corporate identity of their clients other than their own. As part of the review, the concept of corporate identity, corporate image, corporate communication, corporate structure, corporate culture and how design companies implement and designing a corporate identity for themselves will be examined.
\end{abstract}

Keywords: corporate identity, company design, design strategy

\begin{abstract}
ABSTRAK
Penerapan identitas korporasi telah meningkat secara nyata selama 20 tahun dan diprediksi akan terus meningkat di masa mendatang. Design Company ( perusahaan yang menangani desain) akan kena dampak yang paling besar. Dunia usaha percaya bahwa identitas korporasi adalah aspek penting yang harus dipertimbangkan apabila ingin sukses dan berani bersaing dengan perusahaan lain. Artikel menjelaskan teori identitas korporasi yang kemudian akan diterapkan pada suatu Design Company. Banyak perusahaan yang membina identitas korporasi bagi kepentingan klien dan juga perusahaan tersebut. Tinjauan artikel meliputi konsep korporasi, image korporasi, komunikasi, struktur, budaya, dan bagaimana mendesain identitas korporasi bagi kepentingan mereka.
\end{abstract}

Kata kunci: identifikasi korporasi, Desain perusahaan, strategi desain 


\section{INTRODUCTION}

Over the past few years, there has been an increase in the number of publications relating to the subject of corporate identity. The reason for this can be seen in the 1989 MORI survey which showed that 77 percent of leading corporations believe that the importance their company attaches to developing and promoting its corporate identity will increase over the next few years. These surveys are an indication of the market pressures faced by the business world and this is closely connected with the growing competition and awareness, indeed knowledge, in the business world that a corporate identity is of major importance. For the result of any review of corporate identity and updating process to be meaningful, it is necessary to consider the quality of the corporate identity of the design company.

However, a corporate identity is not born overnight, nor can it be purchased like machines. It is developed overtime, as Selame says, "springing from the efforts of key individuals to create and maintain operational principles that emphasize quality and creativity". Many companies, especially design companies try very seriously to develop a corporate identity in their own environment. However, many are too involved in thinking about their client's identity instead of their own.

\section{RESEARCH METHODS}

Article applied library research, in which the theories of corporate identity, corporate image, corporate communication, corporate structure, corporate culture are considered to be the basic analysis of the research.

\section{RESULTS AND DISCUSSION}

The term corporate identity has been described by many experts as 'the real organization according to Ind (1990), 'that reflects who the organization is and the way it actually operates. However, it is still impossible to analyze, measure or observe identity objectively. To begin to understand it, here some definitions of corporate identity from different experts.

Corporate Identity is formed by an organization's history, its belief and philosophy, the nature of its technology, its ownership, its people, the personality of its leaders, its ethical and cultural values and its strategies (Ind, 1990). Corporate identity is expressed in terms of corporate communication, the way the corporation presents itself through design, and its corporate personality, the way decisions are made and the values expressed through decisions and actions (Steidl, 1997).

Corporate identity includes both visual manifestations and non-visual expressions and ways of behavior in relation to social business and political matters, which can be shown, for example, in the behavior of staff, in the style of writing in publications or in the way in which suppliers are treated (Jong de, 1990). Most of those who have written on this subject come from the graphic design discipline and describe why identity is much more that the design itself. Identity, whether corporate or personal, is defined as individuality that means attempting to differentiate oneself from others.

Corporate identity appears to be a recent trend emerging from the need for definition in a complicated world, but, in fact, the history of corporate identity is long. In Ancient Egypt, the Pharaohs used their signatures as a symbol of their administration. Anyone who has been to Luxor can 
attest to the fascination Ramses IV had with his logo that appears virtually everywhere and is especially noticeable because his cartouche is primitive and bold, dominating earlier symbols on columns and buildings (Argenti, 1991).

More contemporary historical examples of corporate identity are evident in the eighteenthcentury U.S. and French revolutions. As a result of those battles, both countries changed their identities with the development of new flags, national anthems and uniforms. During the middle decades of the twentieth century, Nazi Germany terrified the world with its identity program. What is valuable to remember is that, although today we regard the swastika as something abhorrent, the same symbol obviously had strong positive connotations for earlier generations of German nationalists (Argenti, 1991).

Such a symbol, however, be it a Pharaoh's cartouche or nation's flag, is just one dimension of the identity pictures. They receive a lot of attention because of the increasingly visual focus and exposure to this type of shorthand that people can see in television, magazines, annual reports, and brochures. That is one of the reasons why corporate identity is a growing field of activity, as business becomes more and more aware of the importance of presenting a good image to their clients and customers. "Yet despite this awareness, it is a much smaller group of executives and managers that understands a broader definition of identity and how to exploit those perceptions as an essential organizational asset” (Argenti, 1991).

To define corporate identity more specifically, the primary basis for corporate identity is not just a symbol or signature that appears on the letterhead, a trademark or service mark that is used on packaging and advertising. Nor is it just landscape or office interiors, or the signage that points the way to headquarters. It is much broader than that. It is the reality of the organization as a whole.

However, this is frequently hard for anyone but the CEO or Chairman of the company to grasp. Certainly, the products and the services, the people, the buildings, the symbols and other objects contribute to this reality. As Argenti says, "there are inevitably differences in how the elements are perceived, it is this cluster of facts, this collection of tangible things, that provides the organization with a starting point for creating an identity".

As a society becomes more aware of corporate behavior, the company will have more cause to maintain and project its corporate identity. Everything that the company does in every way communicates a message. As Argentibelives, "it will have to demonstrate what it is and what it stands for, through consistency of behavior and performance, to its own staff, its customers and all its other audiences the very sources from which we, the public, derive the opinions".

If the company does this successfully, it means that rumors, myth, gossip and hearsay will for the most part be consistent and favourable and that in an imperfect world is as much as anyone can expect. Inevitably, corporate identity and its management have a crucial role in all this. It is only the most powerful, ubiquitous, well-organized, heavily backed, visually appealing, effectively communicated corporate identity programs that will break through into people's consciousness.

Like it or not, every commercial enterprise has a visual identity. As Bernstein claims, "corporate identity can distinguish a company or extinguish it, depending on the behavior of the company itself”. It may be conveyed by logotype, annual report, letterhead, truck signage, advertising, packaging, architecture or landscaping. More likely, an enterprise's identity lies in the totality of its appearance.

"That so many companies still do not appreciate the role good design can play in shaping attitudes remains a puzzle. Looks may not be everything, but when intelligently applied, they can have a powerful subliminal effect. Corporate identity is more than a new letterhead, a Band-Aid 
solution.....many advertising people recognize the importance of corporate identity in helping to shape overall long term corporate strategies” (Selame, 1988).

On the other hand, "Corporate image is the perception of who the organization is, held by one or more members of the organization's target groups. Obviously, the perceptions of these people likely to be influenced by direct exposure to the organization's identity, its corporate identity, style of communication and its personality as an organization”(Steidl, 1997).

Sometimes the terms image and identity are used interchangeably. Image is not identity. It is the result of identity, the perception of others. Image is a reality. It is the result of actions. If the image is false and the performance is good, it is the fault of bad communication. However, if the image is true and reflects our bad performance, it is the fault of bad management. Unless we know our image, we can neither communicate nor manage.

Corporate images in the eye of the receiver or outsider. A company may transmit a message about itself to its employees, its investors, its clients and all its internal (staff, employee) and external (investor, client) audiences. The corporate image is simply the picture that an audience has of a company. A company may commonly assume that it only communicates when it wants to, but unfortunately, for many companies, a failure to control communicates results in a confused image.

Inevitably, describing the process of creating and controlling a good image for a company is complex. It would involve several months work and, in the case of a big company, it could take years. However, the first thing that can be done is to obtain information about the company through an interview program, including both group discussions and face-to-face interviews. This would encompass a variety of audiences from consumers, suppliers and shareholders to employees (Figure 1).

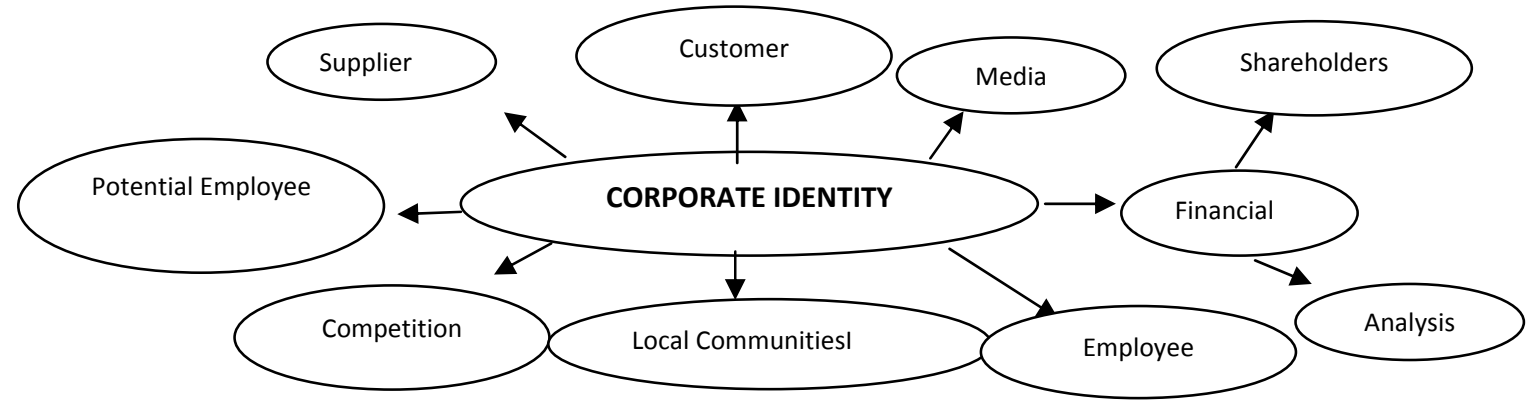

Figure 1 Identity audiences

(Source: Ind, 1990)

Each target group or audience will form an image of that company from the communications it receives. The image can be assessed by a series of one-to-one or group interviews. It can then be compared to the reality of corporate performance, to ascertain whether the image is helping or hindering the achievement of corporate goals. If the image is significantly better than the reality, this implies an operational problem. If the reality is better than the image, this implies a communication problem.

From all the various aspects, it can be concluded that the internal audience (staff, employees) of a company is often the most important audience of an identity program. It is the employees who 
will determine whether an organization is able to meet its objectives who will determine the service or product quality. Moreover, the employees will determine the corporate image.

In addition, because the corporate image is an intangible impression, existing in the minds of people as a subjective opinion, any analysis of a company's position can only be approximate. However, it is essential that objectives of the image program, based on the long-range plans of the company, should be based on careful research.

Corporate communication is the way the corporation "presents itself through corporate design and corporate personality, the way decisions are made and the values expressed through decisions and actions which all help in capturing the essence of the corporate identity” (Ind, 1990).

Corporate communication is the process that translates corporate identity into corporate image. This is a vital part of the process of creating and sustaining a corporate identity because, if a corporate identity is to have any values, this has to be communicated to employees, shareholders and customers. Without communication, the values and strategies of the organization will not be understood and the company will not have any clear sense of identity. It includes everything a company does-from the way that telephones are answered to the way brochures and stationery are presented. As Olins says "the fundamental idea behind a corporate identity program is that in everything a company does, everything it owns, everything it produces, the company should project a clear idea of what it is and what its aims are".

However, communications are becoming ever more expensive, because of global change in the market that make communication systems more complex. This includes the range of communications itself, such as telecommunications and advertising. This makes it even more essential that communication is achieved by ensuring that "a message that a company wants to make can be presented consistently “, in whatever medium is being used (Pildicth, 1970).

Most people think that corporate identity is about symbols, logotypes, colours, typography, even about furniture, products, buildings, about visual design appearance. However, identity can also clarify how a company is organized, and can "indicate whether it is centralized or decentralized, and it can show whether it has divisions, subsidiaries or brands, and how these relate to the whole" (Olins, 1990).

To clarify, the structure of identities can be divided into three separate categories according to Olins (1990): (1) monolithic, where the organization uses one name and visual style throughout. Examples: BMW, IBM; (2) endorsed, where an organization has a group of activities or companies, which it endorses with the group name and identity. Example: General Motors; (3) branded, where the company operates through a series of brands which may be unrelated either to each other or to the corporation. Examples: Procter \& Gamble, Unilever.

These three divisions sound neat and tidy, however in real life the edges between different kinds of identity are often blurred. For example, is something difficult to know where an endorsed identity ends and a branded identity begins. Without necessarily realizing it, a company may evolve from one of these categories into another, frequently in an uneven and uncontrolled fashion.

The decision to clarify an identity and make it work effectively should not be taken rashly. There are, in any company, inconsistencies that need careful consideration. It is worth remembering that none of the three identity categories is intrinsically superior to any other. Each of them has its own advantages and disadvantages, one that is appropriate for one company may be wrong for another. It can be said that changing identities is not easy, because each type has certain strengths and weaknesses. 
One aspect concerned with creating a successful corporate identity is creating a good corporate culture. What is corporate culture? This term is defines as "stating beliefs and values in the company objective, however it sometimes some more strongly than objectives itself” (Garlett, 1988).

Some visible aspects of corporate culture in a company are behavior, actions, communication and environment that people in the company create, and the way people behave, both individually and collectively. All these things reveal what a company really believes about the whole culture of the organization. As an example, take the chairman's statement in the annual report or in any other statement. It may say something like "this company believes that the customer is our first priority" (Garlett, 1988). This is what the company believes their culture, to serve the customer as best they can.

\section{Implementing Corporate Identity}

Every company or business has a corporate identity, which conveys an image to everyone they deal with of who they are, what they do and how they do it. The problem for many companies is that their identities are unmanaged and uncontrolled, leading to poor or unfocused perceptions.

In this section, what is involved in a corporate identity program and how can be implemented will be explained. This explanation is not specific for a given company, but also for any other company that is trying to implement corporate identity.

The approach to producing a corporate identity could be described as "holistic because it touches on everything an organization does "(Ind, 1990). Design plays a very important part in the whole process because one of the ways in which people first judge whether the organization is any good or not, is by what it looks like (its visual appearance).

"Because corporate identity is approached in this reactive way, and it is divorced from the continuing processes of strategic management, a company often lacks the in-house (internal) expertise to address image and identity issues effectively "(Ind, 1990). Corporate identity is a major asset, which needs to be managed on a continuing long term basis.

To work successfully on corporate identities, designers need to use range of skills, not just graphic skills (which naturally, must be excellent). Designers need an understanding of what makes a business tick, otherwise they are designing in a vacuum purely for themselves and not for the clients. The same thing could happen when the design company needs to design a corporate identity for themselves they have to make sure that what they are trying to say about themselves will be understood by their clients.

However, there is one thing that has to be remembered. Different organizations need different approaches. For example, corporate identity for smaller organizations needs to be approached in a different manner from larger companies. A new company, a start up business with no background, history or heritage, no existing customers or clients and existing audience is obviously entirely conceptual at that stage. The analysis and investigation that would normally proceed with an up and running business is in this case, limited to the people who are starting up the business and the handful of clients or customers that they are initially dealing with.

However, if the business does become successful, the company will need an identity that can change as they expand and develop. Not all-corporate identity work starts out on a big scale. Quite often companies are not even aware that they need a corporate identity. They will simply ask for a symbol or logotype to be designed, and gradually as a result of discussion with the designer, it becomes apparent they need something much more comprehensive. 
The design work begins with a detailed analysis of their own's objectives and what clients, people in government, the financial community, shareholders, customs, employees and prospective employees think of their company, and finally, what it is actually saying to them.

Then, after the reports from external and internal research are received, it is the responsibility of company management to review and analyze the corporate image. This becomes the basis for setting the objectives of a new program, resolving problems that may have appeared, and capitalizing on apparent advantages and opportunities. It should again be emphasized that a rapid change in the corporate image is difficult to accomplish. Even a selected audience will be slow to respond. The new image that seems so important to management is not usually of interest to outsiders.

\section{Designing Corporate Identity}

This section will offer readers an understanding of how to design an identity and image for a design company and describes a process for managing a corporate identity program from the visual aesthetics (symbol or logo) to internal organization (culture and structure). Even though it is quite easy to form an image for a company, establishing its identity is a far more difficult task. To identity the real identity, it is necessary to break the company down into its component paths, and look at the company in many different ways.

Actually, most corporate identity programs include design changes. This may include new logos, symbols and colour changes that appear on buildings, uniforms, and other media. Companies try very hard to make these formal identity manifestations unique in order to distinguish themselves from competitors. Through research, the corporation can determine how different constituents perceive the current identity and any changes the organization is contemplating. As Selame says "these investigations, however, must be more than just anecdotal information picked up in a few focus groups "(Selame, 1988). This needs a concentrated effort which takes time, money and patience.

Instead of relying simply on quantitative investigations, companies need to conduct qualitative studies as well. It is not unusual for a firm to rely on the observations of a few people asked at random about their feelings, but a more appropriate undertaking would be an extensive and scientific survey, for example sending out questionnaires to customers and carefully interpreting the findings. Considering the resources involved in implementing an identity program, this could justifiably be considered an investment.

Through this process, corporations must avoid cosmetic changes. Identity is not simply public relations, most analysts are able to see through an image that does not seem to ring true. To make it possible for corporate identity to be implemented, these are some methods that are usually used by design companies to analyze their clients identity and their own identity as well.

\section{CONCLUSION}

Corporate identity is the main focus of this study. In the narrow sense in which the phrase is routinely used by the design profession, corporate identity is one expression of a company's personality. Other expressions of personality come from the approach of staff, the speed and efficiency of action, the company's office or environment, the quality of its designs and other factors.

As Ind says, “corporate identity is formed by an organization's history, its belief and philosophy, the nature of its technology, its ownership, its people, the personality of its leader, its ethical and cultural values and its strategies". ${ }^{36}$ In other meaning, the corporate identity should be 
reflected from the whole aspect of the organization or company, the good corporate identity can create the right personality in the company or organization.

The right personality is something that all companies like to have, but frequently their personality is not what they wish for themselves. Since a corporate identity is the designed expression of a company's personality, it follows that a real change of personality should be followed by considering a change of corporate identity.

In all corporate identity, timing is a crucial. It has been stated that a corporate identity is an expression of a company's personality and thus that a new corporate identity should express a change in personality. The true picture is not so simple. In some cases, it is advantageous to introduce a new identity ahead of the more substantial changes that will modify the corporate personality.

However, it does not follow that a new corporate identity will produce the desired change of personality without other changes also being made. In most companies, the corporate identity must address two principal groups the clients and the staff. However, in some cases it will also be important to influence other group such as potential advertisers, investors or trading partners.

Making changes to an existing corporate identity is far more complex than creating a new identity. A new identity has no history, no equity in the marketplace. The existing identity is an asset, it is recognized in the market and therefore does have great value.

Before embarking on a program to change or alter a company's corporate identity, it is essential that the objectives and desired outcomes of that projected change be made clear, so that potential impact on the market can be considered. The process takes time and a real commitment from everyone involved in company operations.

As Bernstein suggests, "Corporate identity can distinguish a company or extinguish it, depending on the behavior of the company itself". The successful corporate identity reinforces a feeling already created through the client's experience with services or products so that the client is willing to seek out that company in order to purchase the services or products again.

There is growing recognition today that a successful corporate identity can also perform a much-needed internal role by giving company staff a sense of identification with the company they work for. Both clients and staff will know when a company's expression of personality through its corporate identity does not correspond to its actual personality.

Selame strongly believes that "many companies still do not appreciate the role good design can play in shaping attitudes. Looks may not be everything, but when intelligently applied, they can have a powerful subliminal effect”. It can be concluded that corporate identity is a combination of all aspects of the design company, to make the corporate identity work as expected, the first thing that a company should do is consider all the operational procedures and functions : company symbol, stationery, products, interior, building, staff behavior, the company's environment and location.

The implementation of the corporate identity has to be done step by step because a design company cannot just concentrate on their own identity; they have to think about their clients as well, as part of their service and responsibility. Corporate identity is an important determinant in business survival and, indeed, in business success 


\section{REFERENCES}

Argenti, P. (1995). Managing corporate identity. Design Management Journal, Winter 1995, p. 53.

Bernstein, D. (1995). Corporate Tone of Voice. Design Management Journal, Winter 1995, p. 17.

Garlett, T. (1988). How to build a corporation's identity and project its image. Pennsylvania: Lexignton Books.

Ind, N. (1990). The corporate image: Strategies for effective identity programmes. London: Kogan Page.

Jong De, C. (1990). The image of a company: Manual for corporate identity. London, Architecture Design \& Technology.

Market Opinion Research International (MORI). (1989). Study of attitudes of chairman managing director and other mainboard director of Britain's 500 largest companies.

Olins, W. (1990). The Wolff Olins guideto corporate identity. London: Design Council.

Selame, E. (1982). Packaging power: Corporate identity and product recognition. New York: Arnaoon.

Steidl, P., \& Emery, G. (1997). Corporate image and identity satateges designing the corporate future. Australia: Business \& Professional Publishing. 